\title{
Penerapan Metode Weighted Product (WP) Pada Pemilihan Supplier Kimia Terbaik PT. Mayer Indah Indonesia Bogor
}

\author{
Anisah Fitriyani ${ }^{1}$, Rachman Komarudin ${ }^{2}$, Yana Iqbal Maulana ${ }^{3}$, Ali Haidir ${ }^{4}$ \\ STMIK Nusa Mandiri ${ }^{1,2}$, Universitas Bina Sarana Informatika ${ }^{3,4}$ \\ amoyochin00@gmail.com ${ }^{1}$, rachman.rck@nusamandiri.ac.id ${ }^{2}$, yana.yim@bsi.ac.id ${ }^{3}$, ali.alh@bsi.ac.id ${ }^{4}$
}

\begin{abstract}
Abstrak - PT. Mayer Indah Indonesia merupakan perusahaan yang bergerak dalam bidang textile. Dalam rangka menghadapi persaingan bisnis terdapat beberapa permasalahan yang sering muncul yaitu belum memiliki prosedur pemilihan supplier. Pemilihan supplier yang dilakukan bagian pembelian perusahaan saat ini adalah survei langsung dan melakukan perbandingan harga. Sehingga biaya pengiriman menjadi tinggi maupun kemudahan negosiasi dan sistem pembayaran. Sehingga pemilihan supplier perlu dilakukan dengan menggunakan metode yang tepat sesuai dengan standar perusahaan yaitu weighted product (wp) dengan tujuan memberikan informasi kepada perusahaan mengenai metode alternatif yang dapat digunakan dalam memilih supplier secara objektif serta memberikan masukan mengenai performansi dari supplier.
\end{abstract}

Kata kunci : Pemilihan, Supplier Kimia, Terbaik, Weighted Product

Abstract - PT. Mayer Indah Indonesia is a company engaged in the field of textile. In order to face business competition, there are several problems that often arise, namely not having supplier selection procedures. The supplier selection conducted by the company's purchasing department at this time is a direct survey and price comparison. supplier distance with the company so that shipping costs are high and ease of negotiation and payment systems. So the supplier selection needs to be done by using the right method in accordance with company standards, namely weighted product (wp) with the aim of providing information to companies about alternative methods that can be used in objectively selecting suppliers and providing input on the performance of suppliers.

Keywords: Selection, Chemical Supplier, Best, Weighted Product.

\section{PENDAHULUAN}

PT.Mayer Indah Indonesia merupakan perusahaan yang bergerak dalam bidang textile. Dalam rangka menghadapi persaingan bisnis terdapat beberapa permasalahan yang sering muncul yaitu belum memiliki prosedur pemilihan supplier dan kriteria-kriteria yang sesuai dengan standar perusahaan dalam memilih supplier. Pemilihan supplier yang dilakukan bagian pembelian perusahaan saat ini adalah survei langsung dan melakukan perbandingan harga. Beberapa pertimbangan lain yang dihadapi perusahaan saat ini dalam memilih supplier adalah tidak konsisten dalam menyediakan bahan baku yang berkualitas dikarenakan sering terdapat beberapa bahan baku yang tidak sesuai dengan standar perusahaan, keterlambatan bahan baku sampai di gudang yang menyebabkan pihak produksi harus menunda untuk memproduksi dan menyebabkan perusahaan tidak dapat memenuhi target produksi, harga yang ditawarkan beberapa supplier berbeda sehingga menjadi pertimbangan perusahaan, adanya supplier yang sulit dihubungi oleh perusahaan ketika terdapat perubahan jumlah pesanan, beberapa supplier tidak dapat memenuhi permintaan bahan baku sewaktuwaktu karena ketersediaan bahan baku di gudang supplier sehingga perusahaan harus mencari alternatif lain, jarak supplier dengan perusahaan sehingga biaya pengiriman menjadi tinggi maupun kemudahan negosiasi dan sistem pembayaran.
Restaurant XO Suki, salah satu restoran yang sedang berkembang, agar mampu menghasilkan produk/menu makanan yang berkualitas sesuai dengan keinginan customer, Setiap Perusahaan harus menjaga kualitas produksi atau bahan yang mempunyai kualitas tinggi.Beberapa jasa pemasok bahan baku berlomba-lomba ingin mendapatkan keuntungan pada perusahaan Pengambilan keputusan harus dapat menentukan supplier yang tepat dalam menyediakan bahan baku Resturant XO Suki.SPK dengan metode Weight Product merupakan Sistem Pengambilan Keputusan (SPK) berbasis komputer.Kriteria dalam pemilihan supplier:kualitas (K1) Bobot $=3$, pelayanan $(\mathrm{K} 2)$ Bobot $=5$, harga $(\mathrm{K} 3)$ Bobot $=3$, pengiriman (K4) Bobot $=4$, fleksibilitas (K5) Bobot $=2$, Perhitungan WP yang baik yaitu menghasilkan nilai alternatif tertinggi.Restaurant XO Suki ingin melakukan perbaikan terhadap salah satu proses bisnis yang selama ini berjalan di perusahaan,bagian procurement.Masalah utama perusahaan yaitu keterlambatan pengiriman bahan baku yang akan digunakan dalam proses produksi sehingga mengakibatkan proses produksi menjadi terhambat. Alasan lainnya supplier harus mengirimkan bahan baku ke beberapa perusahaan lain dalam waktu bersamaan. Bahan baku menjadi penentu kualitas menu makanan. Pemasok bahan baku pada restoran tidak satu atau dua supplier (Laila \& Sindar, 2019).

Berdasarkan pada latar belakang masalah 
diatas maka permasalahan yang ada yaitu belum adanya penerapan sistem penunjang keputusan, sehingga pemilihan supplier perlu dilakukan dengan menggunakan metode yang tepat sesuai dengan standar perusahaan.

(Pratiwi, 2016) Tujuan Sistem Pendukung Keputusan ini terdiri dari tiga tujuan yang akan dicapai yaitu:

1. Membantu manajer membuat keputusan untuk memecahkan masalah semi terstruktur.

2. Mendukung penilaian manajer bukan mencoba menggantikannya.

3. Meningkatkan efektifitas pengambilan keputusan manajer daripada efisiensinya.

(Suryadi \& Ramdhani, 2017) Mengajukan model yang menggambarkan proses pengambilan keputusan. Proses ini terdiri dari tiga fase, yaitu:

1. Intelligence

Tahap ini merupakan proses penelusuran dan pendeteksian dari lingkup problematika serta proses pengenalan masalah. Data masukan diperoleh, diproses, dan diuji dalam rangka mengidentifikasikan masalah.

2. Design

Tahap ini merupakan proses menemukan, mengembangkan dan menganalisis alternatif tindakan yang biasa dilakukan. Tahap ini meliputi proses untuk mengerti masalah, menurunkan solusi dan menguji kelayakan solusi.

3. Choice

Pada tahap ini dilakukan proses pemilihan diantara berbagai alternatif tindakan yang mungkin dijalankan. Hasil pemilihan tersebut kemudian diimplementasikan dalam proses pengambilan keputusan

\section{METODOLOGI PENELITIAN}

Pada penelitian ini penulis menggunakan metode Weight Product. ((Mulyani et al., 2016) "Perhitungan Weighted Product (WP) ada 3 tahap yaitu, penentuan nilai bobot $W$, penentuan nilai vektor $S$, serta penentuan nilai vektor V".

(Arsyad, 2016) Proses perhitungan Weighted Product (WP) sama halnya dengan proses normalisasi. Dengan rumus sebagai berikut: Menentukan kriteria-kriteria yang akan dijadikan acuan dalam pengambilan keputusan, $\mathrm{Cj}, \mathrm{j}=1$, $2, \ldots, \mathrm{m}$.

Menentukan bobot awal untuk masing-masing kriteria. Nilai bobot awal (w) digunakan untuk menunjukkan tingkat kepentingan relative dari setiap kriteria. Nilai bobot awal ini ditentukan oleh pengambil keputusan yang menentukan tingkat kepentingan relative setiap kriteria. Ada beberapa cara yang biasa dilakukan untuk menentukan bobot awal ini antara lain : Dengan memberikan nilai parameter untuk setiap kriteria atau Memberikan bobot antara $0-100$ yang berarti tingkat kepentingan setiap kriteria. Melakukan normalisasi nilai bobot awal dengan membagi setiap nilai wo dengan total nilai wj. Normalisasi atau perbaikan bobot ini menghasilka nilai normalisasi $w \mathbf{j}=1$ dimana $\mathrm{j}=$ $1,2, \ldots, \mathrm{n}$ adalah banyak alternative dengan

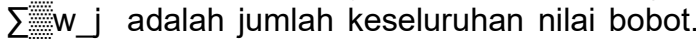
Terdapat 2 sifat yang dimiliki oleh bobot awal berdasarkan pada sifat masing-masing kriteria yaitu keuntungan (benefit) dan biaya (cost). Untuk mencapai solusi ideal, kriteria yang memiliki sifat benefit nilainya akan dimaksimumkan (bernilai positif) sedangkan kriteria yang memiliki sifat cost nilainya akan diminimumkan (bernilai negatif)

Proses perbaikan/normalisasi bobot kriteria (W).

$$
W_{j}=\frac{w j}{\Sigma w j}
$$

Keterangan :

$W_{f} \quad=$ Bobot Atribut

$\sum W_{\tilde{f}} \quad=$ Penjumlahan Bobot Atribut

Menentukan nilai vektor (S). Nilai vektor (S) ini diperoleh dengan cara memangkatkan nilai atribut yang dimiliki setiap kriteria dengan hasil normalisasi bobot yang berpangkat positif untuk kriteria keuntungan (benefit) dan yang berpangkat negatif untuk kriteria biaya (cost).

Proses normalisasi (S) atau Vektor S.

$S_{i}=\prod_{j}^{r}{ }^{\prime}=1 X_{i j} W_{j}$

Keterangan :

$\mathrm{S}_{i}=$ Hasil Normalisasi Matrik

$\mathrm{X}_{\mathrm{j}}=$ Nilai Variabel dari alternatif pada setiap atribut

$\begin{array}{ll}\mathrm{W}_{j} & =\text { Nilai Bobot Kriteria } \\ \mathrm{n} & =\text { Banyaknya Kriteria } \\ \mathrm{i} & =\text { Nilai Alternatif } \\ \mathrm{j} & =\text { Nilai Kriteria }\end{array}$

Menentukan nilai vektor (V) Vektor V merupakan preferensi alternatif yang akan digunakan untuk perangkingan dengan cara membagi masing-masing jumlah nilai vektor $S$ dengan jumlah seluruh vektor $\mathrm{S}$.

Preferensi relatif dari setiap alternatif atau Vektor V.

$V_{i}=\frac{\Pi_{j}^{n}=1 X_{i j} w_{j}}{\Pi_{j}^{n}=1\left(X_{j} * w_{j}\right.}$ 
Keterangan :

$\mathrm{V}_{i}=$ Hasil preferensi alternatif ke-i

$\mathrm{X}_{i j}=$ Nilai Variabel dari alternatif pada setiap atribut

$\mathrm{W}_{j}=$ Nilai Bobot Kriteria

$\mathrm{n}=$ Banyaknya Kriteria

$\mathrm{i}=$ Nilai Alternatif

$\mathrm{j}=$ Nilai Kriteria

* = Banyaknya kriteria yang telah dinilai pada vektor $\mathrm{S}$

Penelitian ini diawali dengan proses pengumpulan data primer melalui survey dan wawancara yang sudah diterima dan sesuai dengan kebutuhan dan kondisi yang ada. Dan selanjutnya penelitian ini juga mencari data sekunder yang diperoleh melalui studi literature, jurnal dan artikel yang berhubungan dengan metode Weighted Product

\section{A. Menentukan Rangking Alternatif}

Dibawah ini Menentukan rangking setiap alternatif pada setiap kriteria dengan $1-5$, penentuan tersebut dapat dilihat seperti Tabel.1 dibawah ini :

Tabel 1. Alternatif Kriteria

\begin{tabular}{ll}
\multicolumn{1}{c}{ Spesifikasi } & \multicolumn{1}{c}{ Biaya } \\
\hline 1 = Sangat Buruk & 1 = Sangat Rendah \\
2 = Buruk & $2=$ Rendah \\
$3=$ Cukup & $3=$ Cukup \\
$4=$ Baik & $4=$ Tinggi \\
5 = Sangat Baik & $5=$ Sangat Tinggi \\
\hline mber : (Febriani, 2018)
\end{tabular}

B. Populasi Penelitian

Tabel 2. Daftar Populasi Supplier PT. Mayer Indah Indonesia

\begin{tabular}{cl}
\hline $\begin{array}{c}\text { Kode } \\
\text { Supplier }\end{array}$ & \multicolumn{1}{c}{ Nama Supplier Kimia } \\
\hline S1 & PT. Sinergia W \\
S2 & PT. Sinarkimia Utama \\
S3 & PT. Persada Bintang \\
S4 & Gemilang Harapan \\
S5 & PT. Alcari \\
S6 & PT. Donomex Paramitha \\
S7 & PT. Indo Colour \\
S8 & PT. Hameko Kemindopra \\
S9 & PT. Hateka Sapta Kimia \\
S10 & PT. Indokemika Jayatama \\
S11 & PT. Dystar \\
S12 & PT. Kharindo Prakarsa \\
S13 & Bhakti Pancawarna \\
S14 & PT. Futan \\
S15 & PT. Antar Niaga \\
S16 & Hanjaya Chemicals \\
S17 & PT. Interchem Plasagro \\
S18 & PT. Clariant Indonesia \\
S19 & PT. Colorindo Aneka Wrn \\
S20 & CV. Harapan Abadi
\end{tabular}

ISSN: 2338-9761 (Online), 2338-8145 (Print)
PT. Laju Sakti Jaya

PT. Seikyo Indochem

PT. Innomarks Global

PT. Eac Indonesia

PT. Inti Sumber Lestari

PT. Lisiang Usaha Che

PT. Sinar Syno Kimia

PT. Lautan Luas Tbk

PT. Titian anugerah

PT. Sarichem Polywrn

PT. Lucky Rejeki

PT. Lentera Mutiara Sejati

PT. Nebraska Pratama

PT. Mitra Kimia Mas

CV. Mitra Kimia Lestari

PT. Purindo Adi

PT. Ryndang Teksindo $\mathrm{CH}$

PT. Persada Bintang

$\begin{array}{ll}\text { S39 } & \text { PT. Trijaya Lestari } \\ \text { S40 } & \text { Warna Jaya Nusant }\end{array}$

S41 PT. Warna Permai

S42 PT. Virya Mitra

S43 PT. Wanka Aromindo

Sumber : PT. Mayer Indah Indonesia (2019)

\section{Sampel Penelitian}

Sampel digunakan pada kondisi jumlah total populasi yang menjadi objek penelitian yang diamati menjadi lebih tepat stategi dengan menggunakan rumus slovin yaitu rumus yang biasa dipakai dalam menentukan jumlah sampel pada suatu populasi (Supriyanto \& Iswandari, 2017).

$\mathrm{n}=\mathrm{N} /\left(1+\left(\mathrm{N} \times \mathrm{e}^{2}\right)\right.$

keterangan :

$\mathrm{n}=$ jumlah sampel

$\mathrm{N}=$ jumlahpopulasi

$\mathrm{e}=$ batas toleransi error $/$ kesalahan $\left(0.005^{2}\right)$

hasil perhitungan sampel :

$$
\begin{aligned}
& \quad n=\mathbf{N} /\left(\mathbf{1}+\left(\mathbf{N} \times \mathbf{e}^{\mathbf{2}}\right)\right. \\
& n=43 /\left(1+\left(43 \times 0.05^{2}\right)\right. \\
& =43 /(1+(43 \times 0.0025) \\
& =43 / 1.1075 \\
& =38.8 \text { dibulatkan jadi } 39
\end{aligned}
$$

Berikut adalah data sampel supplier pada tabel 3:

Tabel 3. Data sample supplier

\begin{tabular}{cl}
\hline $\begin{array}{c}\text { Kode } \\
\text { Supplier }\end{array}$ & \multicolumn{1}{c}{ Nama Supplier Kimia } \\
\hline S1 & PT. Sinergia W \\
S2 & PT. Sinarkimia Utama \\
S3 & PT. Persada Bintang \\
S4 & Gemilang Harapan \\
S5 & PT. Alcari \\
S6 & PT. Donomex Paramitha \\
S7 & PT. Indo Colour
\end{tabular}




\begin{tabular}{|c|c|}
\hline S8 & PT. Hameko Kemindopra \\
\hline S9 & PT. Hateka Sapta Kimia \\
\hline S10 & PT. Indokemika Jayatama \\
\hline S11 & PT. Dystar \\
\hline S12 & PT. Kharindo Prakarsa \\
\hline S13 & Bhakti Pancawarna \\
\hline S14 & PT. Futan \\
\hline S15 & PT. Antar Niaga \\
\hline S16 & Hanjaya Chemicals \\
\hline S17 & PT. Interchem Plasagro \\
\hline S18 & PT. Clariant Indonesia \\
\hline S19 & PT. Colorindo Aneka Wrn \\
\hline S20 & CV. Harapan Abadi \\
\hline S21 & PT. Laju Sakti Jaya \\
\hline S22 & PT. Seikyo Indochem \\
\hline S23 & PT. Innomarks Global \\
\hline S24 & PT. Eac Indonesia \\
\hline S25 & PT. Inti Sumber Lestari \\
\hline S26 & PT. Lisiang Usaha Che \\
\hline S27 & PT. Sinar Syno Kimia \\
\hline S28 & PT. Lautan Luas Tbk \\
\hline S29 & PT. Titian anugerah \\
\hline S30 & PT. Sarichem Polywrn \\
\hline S31 & PT. Lucky Rejeki \\
\hline S32 & PT. Lentera Mutiara Sejati \\
\hline S33 & PT. Nebraska Pratama \\
\hline S34 & PT. Mitra Kimia Mas \\
\hline S35 & CV. Mitra Kimia Lestari \\
\hline S36 & PT. Purindo Adi \\
\hline S37 & PT. Ryndang TeksindoCH \\
\hline S38 & PT. Persada Bintang \\
\hline S39 & PT. Trijaya Lestari \\
\hline
\end{tabular}

Sumber : Data Penelitian 2019

D. Kriteria dan Bobot

Tabel 4. Keterangan Kriteria

\begin{tabular}{cc}
\hline Kriteria & Keterangan \\
\hline C1 & Harga \\
C2 & Kualitas \\
C3 & Jadwal Pengiriman \\
C4 & Pelayanan
\end{tabular}

Sumber : Data Penelitian 2019

Tabel 5. Bobot Perkriteria

\begin{tabular}{cc}
\hline Kriteria & Bobot \\
\hline C1 & 5 \\
C2 & 4 \\
C3 & 4 \\
C4 & 5 \\
\hline Sumber : Data Penelitian 2019
\end{tabular}

\section{E. Perbaikan Bobot Perkriteria}

Setelah mendapatkan nilai bobot pada masingmasing kriteria maka dilakukan perbaikan bobot dari nilai bobot awal. Perbaikan bobot dengan rumus sebagai berikut:

$$
w_{j}=\frac{w_{j}}{\Sigma w_{i}}
$$

Keterangan :

$w_{i}:$ Bobot Atribut

$\Sigma w_{i j}$ : Penjumlahan Bobot Atribut

1. Hasil untuk perhitungan bobot pada kriteria harga $(C 1)$

$$
W_{1}=\frac{5}{5+4+4+5}=0,2222.22 .22 ว
$$

2. Hasil untuk perhitungan bobot pada kriteria kualitas (C2)

$$
W_{2}=\frac{4}{5+4+4+5}=0,277777778
$$

3. Hasil untuk perhitungan bobot pada kriteria jadwal pengiriman (C3)

$$
W_{3}=\frac{4}{5+4+4+5}=0,277777778
$$

4. Hasil untuk perhitungan bobot pada kriteria pelayanan (C4)

$$
W_{4}=\frac{5}{5+4+4+5}=0,222222222
$$

Tabel 6. Perbaikan Bobot

\begin{tabular}{cc}
\hline $\begin{array}{c}\text { Perbaikan } \\
\text { Bobot }\end{array}$ & $\begin{array}{c}\text { Hasil Perbaikan } \\
\text { bobot }\end{array}$ \\
\hline W1 & 0.222222222 \\
W2 & 0.2777777778 \\
W3 & 0.277777778 \\
W4 & 0.222222222 \\
\hline
\end{tabular}

Nilai bobot atau bobot awal (W) masing-masing kriteria telah ditentukan oleh pihak perusahaan.

Tabel 7. Kriteria Nilai Harga (C1)

\begin{tabular}{ccc}
\hline $\begin{array}{c}\text { Kriteria Nilai } \\
\text { Harga }\end{array}$ & Bobot & Nilai \\
\hline$<=40$ & Sangat Rendah & 5 \\
$41-69$ & Rendah & 4 \\
$70-79$ & Cukup & 3 \\
$80-85$ & Tinggi & 2 \\
$>86$ & Sangat Tinggi & 1 \\
\hline
\end{tabular}

Sumber : Data Penelitian 2019

Tabel 8. Kriteria Nilai Kualitas (C2)

\begin{tabular}{ccc}
\hline $\begin{array}{c}\text { Kriteria Nilai } \\
\text { Harga }\end{array}$ & Bobot & Nilai \\
\hline$<=40$ & Sangat Rendah & 5 \\
$41-69$ & Rendah & 4 \\
$70-79$ & Cukup & 3 \\
$80-85$ & Tinggi & 2 \\
$>86$ & Sangat Tinggi & 1 \\
\hline
\end{tabular}

Sumber : Data Penelitian 2019 
Tabel 9.Kriteria Nilai JP (C3)

\begin{tabular}{ccc}
\hline $\begin{array}{c}\text { Kriteria Nilai } \\
\text { Harga }\end{array}$ & Bobot & Nilai \\
\hline$<=40$ & Sangat Rendah & 5 \\
$41-69$ & Rendah & 4 \\
$70-79$ & Cukup & 3 \\
$80-85$ & Tinggi & 2 \\
$>86$ & Sangat Tinggi & 1 \\
\hline
\end{tabular}

Sumber : Data Penelitian 2019

Tabel 10. Kriteria Nilai Pelayanan (C4)

\begin{tabular}{ccc}
\hline $\begin{array}{c}\text { Kriteria Nilai } \\
\text { Harga }\end{array}$ & Bobot & Nilai \\
\hline$<=40$ & Sangat & 5 \\
& Rendah & \\
$41-69$ & Rendah & 4 \\
$70-79$ & Cukup & 3 \\
$80-85$ & Tinggi & 2 \\
$>86$ & Sangat Tinggi & 1 \\
\hline
\end{tabular}

Sumber : Data Penelitian 2019

\section{HASIL DAN PEMBAHASAN}

Dalam melakukan kegiatan memilih supplier terbaik merupakan kegiatan yang dilakukan oleh setiap perusahaan, tetapi ini bukanlah sesuatu hal yang mudah. Banyaknya supplier yang memiliki nilai-nilai yang bagus. Oleh karena itu penelitian ini akan membahas sistem pendukung keputusan dengan menggunakan metode WP (Weighted Product).

A. Data Alternatif

Tabel alternatif merupakan data supplier yang sudah menggunakan perhitungan rumus slovin.

Tabel 11. Tabel Alternatif

\begin{tabular}{|c|c|c|c|c|c|}
\hline Alt. & Nama Supplier & C1 & $\mathrm{C2}$ & $\mathrm{C3}$ & C4 \\
\hline S1 & $\begin{array}{c}\text { PT. Sinergia } \\
\text { Wahana Nusantara }\end{array}$ & 70 & 70 & 20 & 40 \\
\hline S2 & $\begin{array}{l}\text { PT. Sinarkimia } \\
\text { Utama }\end{array}$ & 60 & 70 & 50 & 60 \\
\hline S3 & PT. Persada Bintang & 60 & 60 & 10 & 20 \\
\hline S4 & Gemilang Harapan & 90 & 70 & 30 & 40 \\
\hline S5 & PT. Alcari & 90 & 70 & 80 & 60 \\
\hline S6 & $\begin{array}{l}\text { PT. Donomex } \\
\text { Paramitha }\end{array}$ & 80 & 70 & 30 & 60 \\
\hline S7 & PT. Indo Colour & 80 & 70 & 70 & 50 \\
\hline S8 & $\begin{array}{l}\text { PT. Hameko } \\
\text { Kemindopra }\end{array}$ & 70 & 90 & 90 & 70 \\
\hline s9 & $\begin{array}{l}\text { PT. Hateka Sapta } \\
\text { Kimia }\end{array}$ & 60 & 80 & 40 & 70 \\
\hline S10 & $\begin{array}{l}\text { PT. Indokemika } \\
\text { Jayatama }\end{array}$ & 60 & 70 & 40 & 40 \\
\hline S11 & PT. Dystar & 70 & 70 & 50 & 60 \\
\hline S12 & $\begin{array}{l}\text { PT. Kharindo } \\
\text { Prakarsa }\end{array}$ & 90 & 70 & 20 & 50 \\
\hline S13 & Bhakti Pancawarna & 60 & 60 & 20 & 70 \\
\hline
\end{tabular}

ISSN: 2338-9761 (Online), 2338-8145 (Print)

\begin{tabular}{|c|c|c|c|c|c|c|c|}
\hline Alt. & \multicolumn{3}{|c|}{ Nama Supplier } & C1 & C2 & C3 & C4 \\
\hline S14 & \multicolumn{3}{|c|}{ PT. Futan } & 70 & 90 & 50 & 70 \\
\hline S15 & \multicolumn{3}{|c|}{ PT. Antar Niaga } & 80 & 70 & 30 & 20 \\
\hline S16 & \multicolumn{3}{|c|}{ Hanjaya Chemicals } & 70 & 80 & 50 & 60 \\
\hline S17 & \multicolumn{3}{|c|}{$\begin{array}{l}\text { PT. Interchem } \\
\text { Plasagro }\end{array}$} & 90 & 60 & 20 & 80 \\
\hline S18 & \multicolumn{3}{|c|}{$\begin{array}{l}\text { PT. Clariant } \\
\text { Indonesia }\end{array}$} & 80 & 90 & 60 & 60 \\
\hline S19 & \multicolumn{3}{|c|}{$\begin{array}{l}\text { PT. Colorindo Aneka } \\
\text { Wrn }\end{array}$} & 60 & 80 & 80 & 30 \\
\hline S20 & \multicolumn{3}{|c|}{ CV. Harapan Abadi } & 70 & 90 & 80 & 20 \\
\hline S21 & \multicolumn{3}{|c|}{ PT. Laju Sakti Jaya } & 60 & 20 & 70 & 50 \\
\hline $\mathrm{S} 22$ & \multicolumn{3}{|c|}{$\begin{array}{l}\text { PT. Seikyo } \\
\text { Indochem }\end{array}$} & 80 & 70 & 80 & 20 \\
\hline $\mathrm{S} 23$ & \multicolumn{3}{|c|}{$\begin{array}{l}\text { PT. Innomarks } \\
\text { Global }\end{array}$} & 70 & 70 & 50 & 20 \\
\hline S24 & \multicolumn{3}{|c|}{ PT. Eac Indonesia } & 70 & 90 & 60 & 30 \\
\hline S25 & \multicolumn{3}{|c|}{$\begin{array}{l}\text { PT. Inti Sumber } \\
\text { Lestari }\end{array}$} & 90 & 80 & 60 & 60 \\
\hline S26 & \multicolumn{3}{|c|}{$\begin{array}{l}\text { PT. Lisiang Usaha } \\
\text { Che }\end{array}$} & 90 & 80 & 20 & 50 \\
\hline S27 & \multicolumn{3}{|c|}{$\begin{array}{l}\text { PT. Sinar Syno } \\
\text { Kimia }\end{array}$} & 90 & 80 & 90 & 60 \\
\hline $\mathrm{S} 28$ & \multicolumn{3}{|c|}{$\begin{array}{l}\text { PT. Lautan Luas } \\
\text { Tbk }\end{array}$} & 80 & 60 & 20 & 50 \\
\hline S29 & \multicolumn{3}{|c|}{ PT. Titian anugerah } & 80 & 70 & 40 & 50 \\
\hline $\mathrm{S} 30$ & \multicolumn{3}{|c|}{$\begin{array}{l}\text { PT. Sarichem } \\
\text { Polywrn }\end{array}$} & 70 & 80 & 40 & 50 \\
\hline S31 & \multicolumn{3}{|c|}{ PT. Lucky Rejeki } & 70 & 40 & 20 & 70 \\
\hline S32 & \multicolumn{3}{|c|}{$\begin{array}{c}\text { PT. Lentera Mutiara } \\
\text { Sejati }\end{array}$} & 80 & 60 & 40 & 30 \\
\hline S33 & \multicolumn{3}{|c|}{$\begin{array}{l}\text { PT. Nebraska } \\
\text { Pratama }\end{array}$} & 80 & 90 & 70 & 70 \\
\hline S34 & \multicolumn{3}{|c|}{ PT. Mitra Kimia Mas } & 80 & 80 & 70 & 60 \\
\hline S35 & \multicolumn{3}{|c|}{$\begin{array}{l}\text { CV. Mitra Kimia } \\
\text { Lestari }\end{array}$} & 60 & 40 & 40 & 60 \\
\hline S36 & \multicolumn{3}{|c|}{ PT. Purindo Adi } & 70 & 90 & 40 & 90 \\
\hline S37 & \multicolumn{3}{|c|}{$\begin{array}{l}\text { PT. Ryndang } \\
\text { Teksindo } \mathrm{CH}\end{array}$} & 80 & 90 & 60 & 90 \\
\hline S38 & \multicolumn{3}{|c|}{ PT. Persada Bintang } & 70 & 90 & 30 & 80 \\
\hline S39 & PT. Trije & Iya Le & tari & 60 & 90 & 30 & 80 \\
\hline Sum & $r$ : Data $\mathrm{F}$ & enelit & an 20 & & & & \\
\hline $\mathrm{Ta}$ & 2. $\mathrm{Ma}$ & AILEI & & & & & \\
\hline & Iternatif & & Krite & eria & & & \\
\hline & & C1 & $\mathrm{C} 2$ & C3 & C4 & & \\
\hline & S1 & 3 & 3 & 1 & 1 & & \\
\hline & S2 & 2 & 3 & 2 & 2 & & \\
\hline & S3 & 2 & 2 & 1 & 1 & & \\
\hline & S4 & 5 & 3 & 1 & 1 & & \\
\hline & S5 & 5 & 3 & 4 & 2 & & \\
\hline & S6 & 4 & 3 & 1 & 2 & & \\
\hline & S7 & 4 & 3 & 3 & 2 & & \\
\hline
\end{tabular}




\begin{tabular}{ccccc}
\hline \multirow{2}{*}{ Alternatif } & \multicolumn{4}{c}{ Kriteria } \\
& C1 & C2 & C3 & C4 \\
\hline S8 & 3 & 5 & 5 & 3 \\
S9 & 2 & 4 & 1 & 3 \\
S10 & 2 & 3 & 1 & 1 \\
S11 & 3 & 3 & 2 & 2 \\
S12 & 5 & 3 & 1 & 2 \\
S13 & 2 & 2 & 1 & 3 \\
S14 & 3 & 5 & 2 & 3 \\
S15 & 4 & 3 & 1 & 1 \\
S16 & 3 & 4 & 2 & 2 \\
S17 & 5 & 2 & 1 & 4 \\
S18 & 4 & 5 & 2 & 2 \\
S19 & 2 & 4 & 4 & 1 \\
S20 & 3 & 5 & 4 & 1 \\
S21 & 2 & 1 & 3 & 2 \\
S22 & 4 & 3 & 4 & 1 \\
S23 & 3 & 3 & 2 & 1 \\
S24 & 3 & 5 & 2 & 1 \\
S25 & 5 & 4 & 2 & 2 \\
S26 & 5 & 4 & 1 & 2 \\
S27 & 5 & 4 & 5 & 2 \\
S28 & 4 & 2 & 1 & 2 \\
S29 & 4 & 3 & 1 & 2 \\
S30 & 3 & 4 & 1 & 2 \\
S31 & 3 & 1 & 1 & 3 \\
S32 & 4 & 2 & 1 & 1 \\
S33 & 4 & 5 & 3 & 3 \\
S34 & 4 & 4 & 3 & 2 \\
S35 & 2 & 1 & 1 & 2 \\
S36 & 3 & 5 & 1 & 5 \\
S37 & 4 & 5 & 2 & 5 \\
S38 & 3 & 5 & 1 & 4 \\
S39 & 2 & 5 & 1 & 4 \\
\hline Sumber : Data Penelitian 2019 &
\end{tabular}

Sumber : Data Penelitian 2019

B. Perhitungan Nilai Vektor (S)

Setelah dilakukan perbaikan bobot, dilakukan perhitungan nilai vektor (S), dengan memangkatkan dan mengalikan nilai masingmasing kriteria tersebut dengan bobot yang sudah diperbaiki sebelumnya. Perhitungan nilai vektor (S) dari data tabel IV.2 dan tabel IV.6 dengan rumus:

$S_{i}=\prod_{j=1}^{n} X_{i j} W_{j}$

Keterangan :

$S_{i} \quad$ : Hasil Nurmalisasi Matrik

$X_{i f} \quad$ : Nilai Variabel dari alternative pada setiap atribut

$$
\begin{array}{ll}
W_{i} & \text { : Nilai Bobot Kriteria } \\
\mathrm{n} & \text { : Banyaknya Kriteria } \\
\mathrm{i} & \text { : Nilai Alternatif } \\
\mathrm{j} & \text { : Nilai Kriteria }
\end{array}
$$

Perhitungan:

1. Hasil perhitungan dari masing-masing kriteria pada alternative 1 adalah 1,732050808

$S_{1}=3^{0,222222222} \times 3^{0,27 w 778} \times 1^{0,27 w 7 w 8} \times 1^{0,2222222222}=1,732050808$

2. Hasil perhitungan dari masing-masing kriteria pada alternative 2 adalah 2,238433693

$S_{2}=2^{0,2222222222} \times 3^{0,27777778} \times 2^{0,2787778} \times 2^{0,222222222}=2,238433693$

Pada Tabel IV.8 merupakan Preferensi Vektor $S$ yaitu hasil nilai dari setiap alternatif serta jumlah total seluruh nilai vektor $\mathrm{S}$.

Tabel 13. Nilai Preferensi Vektor $\mathrm{S}$

\begin{tabular}{cr}
\hline Vektor S & Hasil Pemangkatan Nilai \\
\hline S1 & 1.732050808 \\
S2 & 2.238433693 \\
S3 & 1.414213562 \\
S4 & 1.940261872 \\
S5 & 3.32655563 \\
S6 & 2.153874257 \\
S7 & 2.922496687 \\
S8 & 3.984469989 \\
S9 & 2.188574761 \\
S10 & 1.582811644 \\
S11 & 2.449489743 \\
S12 & 2.263371818 \\
S13 & 1.805269078 \\
S14 & 3.089097875 \\
S15 & 1.846395747 \\
S16 & 2.653266232 \\
S17 & 2.359050403 \\
S18 & 3.009292769 \\
S19 & 2.5198421 \\
S20 & 2.933757187 \\
S21 & 1.846395747 \\
S22 & 2.713711515 \\
S23 & 2.099810343 \\
S24 & 2.419940697 \\
S25 & 2.972217261 \\
S26 & 2.451664896 \\
S27 & 3.833711638 \\
S28 & 1.924447674 \\
S29 & 2.153874257 \\
S30 & 2.188574761
\end{tabular}




\begin{tabular}{cr}
\hline Vektor S & Hasil Pemangkatan Nilai \\
\hline S31 & 1.629498222 \\
S32 & 1.781797436 \\
S33 & 3.685615885 \\
S34 & 3.165623288 \\
S35 & 1.36079 \\
S36 & 2.854381038 \\
S37 & 3.688888722 \\
S38 & 2.716291591 \\
S39 & 2.482247022 \\
Total & $\mathbf{9 6 . 3 8 2 0 5 7 8 5}$ \\
\hline Data Penelitian 2019
\end{tabular}

\section{Menghitung Nilai Vektor (V)}

Setelah mendapatkan nilai Vektor (S) langkah selanjutnya yaitu menentukan nilai vektor (V) yaitu, membagi preferensi setiap alternatif dengan jumlah total vektor $S$ dengan rumus:

$V_{i}=\frac{\pi_{i}^{\mathrm{n}}=1 X_{\mathrm{ij}} W_{i}}{\pi_{i}^{\mathrm{n}}=1\left(X_{j}, W_{j}\right.}$

Keterangan :

$V_{i}=$ Hasil preferensi alternatif ke-i

$x_{\mathrm{V}}=$ Nilai variabel dari alternatif pada setiap

atribut

$w_{j}=$ Nilai bobot kriteria

$\mathrm{N}=$ Banyaknya kriteria

$\mathrm{I}=$ Nilai alternative

$\mathrm{J}=$ Nilai kriteria

*= Banyaknya kriteria yang telah dinilai pada vektor S

Perhitungan:

1. Hasil perhitungan vektor $V$ pada alternatif 1 dengan nilai 1,732050808 adalah 0,018315143

$$
V_{1}-\frac{1,732050808}{96,38205785}-0,018315143
$$

2. Hasil perhitungan vektor $V$ pada alternatif 2 dengan nilai 2,238433693adalah 0,023669764

$$
V_{2}=\frac{2,238433693}{96,38205785}=0,023669764
$$

\section{Hasil Nilai Vektor V}

Tabel 14. Hasil Nilai Vektor V

\begin{tabular}{cc}
\hline Vektor V & Hasil Nilai Vektor (V) \\
\hline V1 & 0.017970677 \\
V2 & 0.023224589 \\
V3 & 0.014672996 \\
V4 & 0.020130945 \\
V5 & 0.034514262 \\
V6 & 0.022347253 \\
V7 & 0.030321999
\end{tabular}

\begin{tabular}{cc}
\hline Vektor V & Hasil Nilai Vektor $(\mathbf{V})$ \\
\hline V8 & 0.041340371 \\
V9 & 0.022707284 \\
V10 & 0.016422264 \\
V11 & 0.025414375 \\
V12 & 0.023483332 \\
V13 & 0.018730344 \\
V14 & 0.032050549 \\
V15 & 0.019157048 \\
V16 & 0.027528632 \\
V17 & 0.024476033 \\
V18 & 0.031222541 \\
V19 & 0.026144307 \\
V20 & 0.030438831 \\
V21 & 0.019157048 \\
V22 & 0.028155775 \\
V23 & 0.02178632 \\
V24 & 0.025107792 \\
V25 & 0.030837869 \\
V26 & 0.025436943 \\
V27 & 0.039776196 \\
V28 & 0.019966866 \\
V29 & 0.022347253 \\
V30 & 0.022707284 \\
V31 & 0.016906655 \\
V32 & 0.018486817 \\
V33 & 0.038239647 \\
V34 & 0.032844529 \\
V35 & 0.014118707 \\
V36 & 0.029615274 \\
V37 & 0.038273604 \\
V38 & 0.028182544 \\
V39 & 0.025754244 \\
Vata Pent
\end{tabular}

Sumber : Data Penelitian 2019

\section{E. Menentukan Hasil}

Langkah terakhir yaitu merengking data yang telah dihitung berdasarkan nilai vektor $\mathrm{V}$ dari nilai yang terbesar hingga yang terkecil.

\section{G. Rangking Nilai Alternatif}

Tabel 15. Preferensi Alternatif

\begin{tabular}{ccc}
\hline $\begin{array}{c}\text { Preferensi } \\
\text { Alternatif }\end{array}$ & $\begin{array}{c}\text { Nilai Vektor } \\
\text { V }\end{array}$ & Peringkat \\
\hline V1 & 0.018315143 & 32 \\
V2 & 0.023669764 & 21 \\
V3 & 0.014954252 & 34 \\
V4 & 0.020516819 & 26 \\
V5 & 0.03517584 & 36 \\
V6 & 0.022775611 & 23 \\
V7 & 0.030903219 & 9 \\
V8 & 0.041525928 & 1 \\
V9 & 0.02259833 & 38 \\
V10 & 0.01673705 & 39 \\
V11 & 0.025901524 & 17
\end{tabular}




\begin{tabular}{|c|c|c|}
\hline V12 & 0.023933466 & 20 \\
\hline V13 & 0.019089371 & 30 \\
\hline V14 & 0.032664902 & 6 \\
\hline V15 & 0.019524255 & 28 \\
\hline V16 & 0.028056308 & 13 \\
\hline V17 & 0.024945195 & 19 \\
\hline V18 & 0.031821022 & 7 \\
\hline V19 & 0.026645447 & 14 \\
\hline V20 & 0.03102229 & 37 \\
\hline V21 & 0.019157048 & 29 \\
\hline V22 & 0.028695471 & 12 \\
\hline V23 & 0.022203925 & 25 \\
\hline V24 & 0.025589064 & 18 \\
\hline V25 & 0.031428976 & 8 \\
\hline V26 & 0.025924524 & 16 \\
\hline V27 & 0.040538636 & 2 \\
\hline V28 & 0.020349596 & 27 \\
\hline V29 & 0.022775611 & 24 \\
\hline V30 & 0.023142543 & 22 \\
\hline V31 & 0.017230726 & 33 \\
\hline V32 & 0.018841176 & 31 \\
\hline V33 & 0.038972634 & 4 \\
\hline V34 & 0.033474101 & 5 \\
\hline V35 & 0.014389337 & 35 \\
\hline V36 & 0.030182946 & 10 \\
\hline V37 & 0.039007242 & 3 \\
\hline V38 & 0.028722754 & 11 \\
\hline V39 & 0.026247907 & 15 \\
\hline
\end{tabular}

Sumber : Data Penelitian 2019

Maka sesuai dengan hasil perhitungan menggunakan metode Weighted Product untuk penyeleksian supplier pada Tabel IV.10 didapatkan alternatif terbaik yaitu V8 (PT. Hameko Kemindopra) dengan nilai 0.041525928 .

\section{KESIMPULAN}

Data supplier yang diperoleh dari perusahaan PT. Mayer Indah Indonesia sebanyak 43 data dari perhitungan menggunakan rumus slovin dapat diperoleh menjadi 39 data,Dengan menerapkan metode Weighted Product dari hasil yang telah diolah dalam perhitungan maka di dapat PT Hameko Kemindopra menjadi supplier terbaik dengan nilai vektor 0,041340371, Hasil Hipotesis adanya hubungan antar kriteria untuk pemilihan supplier terbaik yang digunakan dalam pembobotan. Penelitian pemilihan supplier dapat dilakukan pada perusahaan lainnya dan dapat dikembangkan dengan metode penelitian yang lain, seperti profile matcing, simple additive weighting, ELECTRE, Promethee, AHP,Penelitian ini dapat dikembangkan lebih lanjut dengan kriteria-kriteria yang berbeda sesuai dengan kriteria dan bobot yang ditentukan pada setiap masing-masing perusahaan.

\section{REFERENSI}

Arsyad, M. (2016). Sistem Pendukung Keputusan Untuk Seleksi Calon Ketua Badan Eksekutif Mahasiswa ( BEM ) STMIK Banjarbaru Dengan Metode Weighted Product ( WP ) Muhammad Arsyad. Jurnal Bianglala Informatika, 4(1), 51-59.

Laila, F., \& Sindar, A. (2019). Penentuan Supplier Bahan Baku Restaurant XO Suki Menggunakan Metode Weight Product. 2(April), 1-4.

Mulyani, E. D. S., Sugihato, A., \& Agustian, R. (2016). Penyeleksian Siswa Partner Schulen Der Zukunft dengan Metode Weighted Product (WP) di SMAN 3 Tasikmalaya. Creative Information Technology Journal, 3(4), 319. https://doi.org/10.24076/citec.2016v3i4.87

Pratiwi, H. (2016). Buku Ajar (Sistem Pendukung Keputusan). Deepublish.

Supriyanto, W., \& Iswandari, R. (2017). Kecenderungan Sivitas Akademika dalam Memilih Sumber Referensi untuk Penyusunan Karya Tulis IImiah di Perguruan Tinggi. Berkala IImu Perpustakaan Dan Informasi, 13(1), 79. https://doi.org/10.22146/bip.26074

Suryadi, K., \& Ramdhani, M. A. (2017). Sistem Pendukung Keputusan (Suatu Wacana Struktual Idealisasi dan Implementasi Konsep Pengambilan Keputusan). Remaja Rosdakarya Offset. 